\title{
$5,5^{\prime}$, Azophthalide.
}

This was obtained by the action of a 2 per cent. sodium amalgam upon the dilute alkaline solution of $p$-nitrophthalide. $\mathrm{Hy}$ drochloric acid is added to the resultant alkaline solution, and the red precipitate obtained is filtered off and dried. From dilute alcohol, it forms small red crystals, melting with decomposition at $260^{\circ}-280^{\circ}$. It is sparingly soluble in hot water, moderately in hot alcohol or glacial acetic acid.

0.2000 gram substance gave $17.6 \mathrm{cc}$. nitrogen at $26^{\circ}$ and $75^{6} \mathrm{~mm}$.

$\begin{array}{cc}\text { Calculated for } \mathrm{C}_{10} \mathrm{H}_{10} \mathrm{O}_{4} \mathrm{~N}_{\Omega} . & \text { Found. } \\ \text { Nitrogen } \ldots \ldots \ldots \ldots \ldots \ldots \ldots & 9.5\end{array}$

This work is being continued and other papers upon the subject will be published.

ORGANIC IABORATORY, HAVEMEYER HALI, COLUMBIA UNIVERSITX, July I, IgoI.

\section{ON THE EXISTENCE OF A NEW ELEMENT ASSOCIATED WITH THORIUM. ${ }^{1}$}

By ChARLES BASKERVILLE.

Received August 15, 1901 .

$A$ LMOST five years ago I attempted to separate thorium tion with sulphur dioxide and boiling. As may be recalled, this was merely an application of the method formerly made known by me and used in the separation of zirconium ${ }^{2}$ and titanium. ${ }^{3}$ The separation of thorium by this means was not quantitative. On resolution of the precipitated portion in hydrochloric acid and exact neutralization with ammonium hydroxide and treatment again with sulphur dioxide, almost complete precipitation resulted, showing that the initial partial precipitation was not altogether due to imperfect action of the precipitant or the solubility of the basic thorium sulphite in the netutral menstruum. This was verified by many repetitions of the process using thorium chloride solutions of different strengths and varying amounts of ammonium chloride.

1 Presented at the Denver meeting of the American Chemical society.

2 Chem. News, 70, 57 (I894); This Journal, I6, 475 (1894).

3 This Journal, 16, 437 (I894).

4 These basic sulphites are being investigated at present. It may be well to state that in addition to a flocculent basic sulphite there has been obtained a gelatinous compound, or hydrogeie, similar in appearance to the zirconium sulphite described by venable and Baskerville, this Journal, 17, 448 (1895). 
These solutions were first made upon fairly pure thorium salts prepared by me from oxides obtained from analyses of many monazite sands for the North Carolina Geological Survey.' As this conduct was unexpected and not in keeping with the observed reactions of the group, the experiments were repeated with thorium compounds obtained from different sources with like results. I was favored with several grams of thorium sulphate prepared by Professor Dunnington, of Virginia, from monazite sand found in Amelia County (Va). Prof. Dennis, of Cornell, kindly gave me 3.5 grams thorium nitrate ( 99.6 per cent. pure). The hydroxide from which it had been prepared was separated by means of potassium hydronitrate." I worked up about 5,000 liters of thorium sulphate solution obtained from Carolina monazite kindly collected by the late Mr. H. B. C. Nitze, assistant state geologist. The procedure followed need not be detailed here, as it will appear in a subsequent and more extended communication. Finally, Dr. Waldron Shapleigh generously gave me 2 kilograms of the purest thorium oxalate to be had at the Ater Welsbach works. My thanks are due these gentlemen for their kindness."

The purest thorium compounds were repurified by the following procedure: The sulphate was taken up in cold water, treated with sodium sulphate and allowed to stand from twelve to twentyfour hours to insure separation of the remaining cerium salts, the percentage of which was quite small. The liquid was filtered

1 Bulletin 9, "Monazite and Monazite Deposits in N. C.," I895.

" This Journal, 18, 947 (1896).

While in the midst of repurifying the compounds from such varied sources and desiring to leave no stone unturned in the investigation, during the fall of last year I wrote Prof. Bohuslav Brauner, of Prague, of my observations and requested a small amount of the purified thorium compound used by him in his excellent work on the atomic weight of that element (/. Chem. Soc., London (Trans.), 73, 991 (I898)). Very likely the letterwent astray as I have received no reply. I was surprised, therefore, to observe in the proceedings of the London Chemical Society (April 10, rgor), an article by him on "Contributions to the Chemistry of Thorium," in which he gives good evidence of the complexity of thorium, dividing that element into Tha and The. Immediately at my first opportunity (April 23), at the spring meeting of the $N$. C. Section of the American Chemical Society, I made public mention of my work, which had been discussed often in private with others. Brauner's results were obtained by hydrolysis of the heptahydrated thorium tetrammonium oxalate. This communication contains in part the results of my experiments reported then and some observations made since. As soon as the unexpected properties were 110 ted almost five years ago, I indicated the differences by terming one Th and the other $T h(x)$. It is deemed well to make this explanation in presenting a preliminary paper on incomplete work, as it was done independently and the problem was attacked in a different way. Results have been obtained which corroborate Brauner's work. It may also be stated that large quantities of the materials are being worked up and the work will be pushed to a finality. 
and the hydroxide precipitated in tall cylinders by a large excess of chemically pure sodium nitrite. This precipitate was washed by decantation from six to ten times, using 20 volumes (to I of precipitate) of distilled water each time. To remove the last of the sodium salts and other soluble impurities the precipitate was then dissolved in hydrochloric acid reprecipitated by slight excess of ammonium hydroxide and washed by decantation at least ten times, using 20 volumes of distilled water.

I. VARIATION IN THE SPECIFIC GRAVITY OF THE OXIDE.

The determination of the specific gravity of the oxides affords a rapid and excellent means of judging the rate of fractionation and in a measure the purity of the rare earths. This method has been especially urged independently by Muthmann and Bohm ${ }^{1}$ as having time advantages over the necessarily long and often tedious equivalent determinations. Brauner also uses the method. The oxide obtained by prolonged ignition with the blast of the purified hydroxide obtained above had a specific gravity of IO. I corrected to $4^{\circ} \mathrm{C}$. Clarke, in his "Constants of Nature," gives the following values :

Name and formula. Thorium dioxide, $\mathrm{ThO}_{2}$.

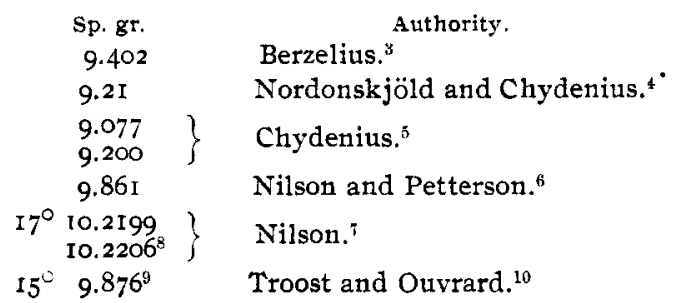

About io grams of the purified hydroxide obtained above were again dissolved in hydrochloric acid, made up to about $300 \mathrm{cc}$, and exactly neutralized by dilute ammonium hydroxide. To insure neutrality, the ammonia was added until the slightest permanent precipitate remained after stirring the cold solution vigorously for five minutes. The precipitate was separated by

1 Ber. d. chem. Ges., 33, No. I; Chem. News, 81, I81.

2 Smithsonian Institution, Part I, p. 48 (I868).

3 Pogg. Ann., 16, $3^{85}$.

4 Jsb. Chem, I3, I34.

5 Ibid., 16, I94.

6 Compt. rend., $91,232$.

7 Ber.d. chem. Ges., is, 2336 .

8 Reduced to $4^{\circ} \mathrm{C}$., this value is 10.201 .

9 Clarke gives a note stating that Nilson's determination is the only one of value.

10 Compt. rend., 102, 1422. 
f.ltration and the solution saturated with freshly prepared and washer sulphur dioxide. Within a few minutes a flocculent basic sulphite began to separate. As the reaction continued in the cold the precipitate increased and then decreased somewhat. The solution was filtered cold and the filtrate boiled giving a second but much smaller precipitate similar to the first, showing that the precipitate is soluble to some extent in the cold sulphurous acid solution. The hot filtrate was then precipitated with a slight excess of ammonium hydroxide and filtered off. Portions of the sulphite and ammonia precipitates were removed from the funnels, care being taken that they were not contaminated with the ashless filter-paper, ignited in platinum crucibles with the blast and the specific gravity of the oxides determined.

Before treatment. IO. I

\section{Sulphur dioxide
precipitate.} $9 \cdot 38$
Soluble portion precipitated by ammonia $10.367^{1}$

Twenty grams of Shapleigh's purest thorium oxalate were repurified according to the method given above. A saturated solution of chemically pure citric acid was prepared and the pure hydroxide added in excess; $i$. $e$, until no more was dissolved cold when the stirring had continued (by means of a motor) for from twelve to fifteen hours (different experiments). In attempting to concentrate the filtered solution by heat a heary white precipitate, resembling in a measure barium sulphate in appearance, came down. The utmost care was necessary in boiling the solution as the bumping was often quite violent. The precipitate redissolved when the solution was cooled. In eraporating the solution on the water-bath the precipitate appeared and was dissolved again on cooling.

A thorium citrate is described by Chydenius ${ }^{2}$ but he did not investigate it further than to determine the percentage of oxide present. The investigation of this citrate, not previously noted, is well under way and will be published later as a separate paper. For our purposes here it suffices to state that the precipitate may best be obtained and separated by diluting the solution from five to ten times and holding it at or just below $100^{\circ} \mathrm{C}$. This has been done by placing the large beaker (Jena glass) into a boiling waterbath for an hour. The precipitate settled well and the clear

All determinations here and elsewhere in this paper were corrected to $4^{\circ} \mathrm{C}$.

" Pogg. Ann, 119. 55 (1863) ; "Kemisk undersökning of Thotzord och Thorsalter" Helsingfoss, $186 \mathrm{I}$. 
supernatant liquid was decanted; the precipitate was washed several times with boiling water by decantation, the settling occurring while the beaker was surrounded by boiling water. Finally the precipitate was thrown upon a large filter-paper and washed several times with boiling water, or until the wash-water was only faintly acid to litmus. The precipitate was carefully removed from the funnel, avoiding contamination with fibers of the filter-paper, and brought to a constant weight at $105^{\circ} \mathrm{C}$. in an air-bath. Prepared thus the body is a beautiful white heavy amorphous powder and is an hydrated citrate of the real thorium.

Portions of this purified citrate made at different times were ignited in platinum crucibles with blast, and the specific gravity of the oxides determined.

$\begin{array}{cc}\begin{array}{c}\text { Oxide taken. } \\ \text { Gram. }\end{array} & \begin{array}{c}\text { Specific gravity } \\ \text { corrected to } 4^{\circ} \mathrm{C}\end{array} \\ 0.1989 & 9.234 \\ 0.6000 & 9.253 \\ 0.3830 & 9.210 \\ 0.4166 & 9.188^{1}\end{array}$

From these determinations it appears that Nordenskjöld and Chydenius very likely at one time had the nearly pure thorium compound. I am inclined to the opinion that the oxide obtained by me above is still not quite pure for reasons given below. (See also radio-active experiments.) One of the regrettable features of the paper is that I am unable yet to submit the results of the spectroscopic investigation of the material. Preliminary atomic weight determinations have been made from this oxide, however.

The filtrates (without the wash-water) obtained from the citrate mentioned above were concentrated in platinum on a water-bath. As the solution became concentrated a little more of the insoluble citrate separated out, but in one series of the experiments no effort was made to separate it, but the whole was carried down to a thick sirup and allowed to cool, when it became a mass of solid crystals, more or less opaque from the insoluble citrate bound up with the mass. Two grams of this material were ignited and the specific gravity of the oxide determined:

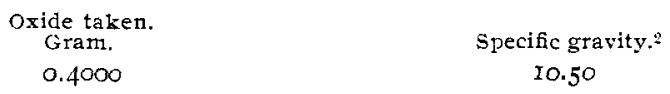

1 Citrate prepared from second heating of one of the solutions which was not completely precipitated at first.

2 Mr. R. O. E. Davis, assistant in the laboratory, aided in sone of the physical constant determinations. He is at present at work on the citrates and molybdates. 
A larger quantity of the saturated citrate solution was prepraed dan most of the insoluble citrate removed according to the method given. About 2 liters of filtrate (wash-water not included) were concentrated to $400 \mathrm{cc}$. in platinum on the water-bath when a crystalline scum began to form. The dish was covered and allowed to stand over night. A few heavy crystals separated at the bottom. The thick sirup was drained from the crystals which, without crushing, were then washed three times with water, and dried at $120^{\circ} \mathrm{C}$. On ignition, $31.6 \mathrm{I}$ per cent. of oxide was obtained. The specific gravity of the oxide was determined.

$\begin{array}{lc}\text { Oxide taken. } & \\ \text { Gram. } & \text { Specific gravity. } \\ 0.1789 & 8.77 \\ 0.2024 & 8.47\end{array}$

What this oxide is I am unable to say, unless it be the new body recently reported by Hofman and Prandt $1^{1}$ as a contamination of zirconium in euxenite. It constitutes only a very small percentage of the thorium and demands careful investigation, which I cannot at present undertake on account of the wealth of other material demanding more immediate attention. I should like to have the privilege of investigating it later, however.

When the sirup obtained above was further evaporated to about 300 cc., a white crystalline body separated and formed a thick coating on the bottom of the dish. The liquid was decanted, and the crystals washed until the water was only faintly acid, and dried at $120^{\circ} \mathrm{C}$. The residue amounted to 16.20 per cent. after ignition, and had a specific gravity of I0.14, using 0.3820 gram of oxide.

On continued concentration small crops of crystals were obtained consisting primarily of citric acid with decreasing percentages of oxide. These salts have not yet been closely studied. When the sirup was brought to about $200 \mathrm{cc}$. it was diluted approximately to a liter and boiled. A small precipitate very similar to the first insoluble thorium citrate, yet different, was obtained. The oxide obtained when the material was ignited was exceedingly white.

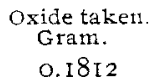

Specific gravity.

I. I. 26

As the quantity of the material obtained was very small, too much weight should not be given to this value.

1 Ber, d. chem. Ges, 34, 1064 (Igor). 


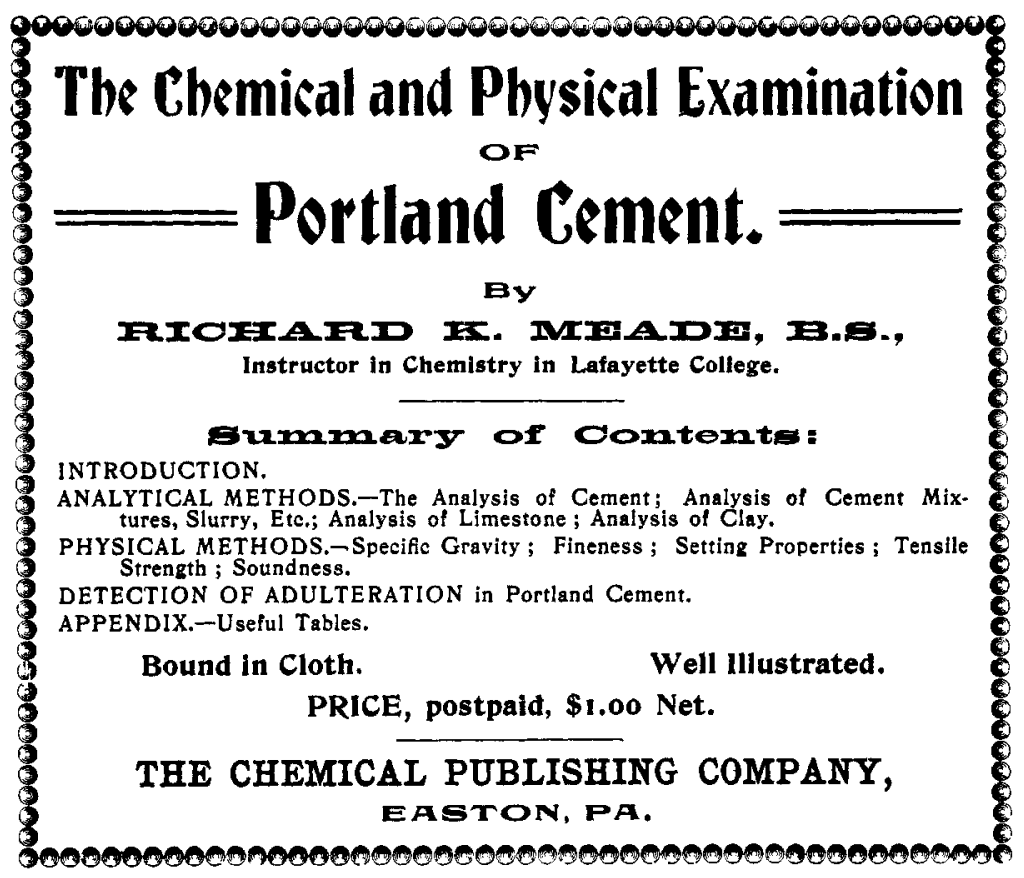




\section{SITUATIONS WANTED.}

"Members seeking employment are invited to insert a notice to that effect in the advertising columns of the Journal, free of charge, the notice not to exceed the space of three one-half inch insertions."

POSITION wanted as superintendent or in office of chemical concern.

Have had eight year's experience in laboratory and factory, manufacturing cement, crucibles, acids, heavy chemicals, hydrogen dioxide and dyestuffs, with their application. Can give the best of references. Address " $\mathrm{H}_{2} \mathrm{O}_{2}$," care Journal of American Chemical Society.

CHEMIST, graduate of leading German university, desires good position ( with manufacturing concern. Can furnish excellent references. Knows French and German. At present employed. Address "B. I. W.." care Journal of American Chemical Society.

CHEMIST with thorough university training and two years' experience in C laboratory of large chemical factory desires position. Address "Crucible," care Journal of American Chemical Society.

WANED. - Position as assistant chemist in cane factory in Cuba or Mexico, for the coming season. References furnished. Address, Box IOI, Norfolk, Nebr.

A GRADUATE (June, Igor) of an eastern scientific school, with the deA gree of Bachelor of Science in chemistry, Cum I-aude, desires a position as chemist to a factory in or near New York. Address "H. A. R.." FoI Madison Street, Brooklyn, N. Y.

CHEMIST.-Technical graduate, thoroughly experienced in iron, copper, and fertilizer work-desires to make a change. At present chemist for plant of two large iron furnaces. Position as instructor or in experiment station laboratory preferred. Address "Sulphur," care Jonmal of American Chemical Society.

MASS. INST. OF TECH, graduate in chemistry, with two years' experi. $M$ ence as private assistant and instructor in chetnistry, would like a position in some technical line. Address "W." care Journal of American Chenical Society.

II

TECHNICAL chenist, having deroted years to the study of malting, brewing, and fermentation; and having made a specialty of the above, including the bacteriology of pure yeast culture, desires responsible position as technical manager. Address "Bacteriology," care Journal of American Chemical Society.

WANTED.-Position by chemist, Ph.M. Over two years in charge of general laboratory. Address, "Iodine," care Journal of American Chemical Society.

A COLLEGE graduate with two years' laboratory experience wishes a A position. Industrial work preferred. Experience in this line. Address, "X. Y.," Room 28, 47 Broadway, New York City.

TNIVERSITY of Pennsylvania graduate in chemistry, age 24, wishes position as instructor in chemistry at a school or college. Desires to locate in the west. Best of references. Address, "I. P. M." care Journal of American Chemical Society.

10

\section{WANTED.}

A SSISTANT in laboratory of industrial plant. Must be graduate in chem$A$ istry. State qualifications and experience. Address P. O. Box 893, Cincinnati, Ohio.

\section{FOR SALE CHEAP.}

\section{Allen's Commercial Organic Analysis, Latest Edition. Six Volumes. Good as new.

\author{
Box 4028, Station B.,
}

Philadelphia, Pa. 
Two portions of the filtrate from this precipitate were evaporated to dryness in a platinum dish, ignited, and the specific gravity of the residue determined:

$\begin{array}{ccc}\text { Oxide taken. } & \text { Gram. } & \text { Specific gravity. } \\ \text { I. } & 0.3560 & 10.46 \\ \text { II. } & 0.8316 & 10.53\end{array}$

II was strongly ignited in a covered platinum crucible for three hours.

These determinations prove the presence of an oxide having an unusually high specific gravity, which cannot be accounted for except by the presence of either a new oxide of a known element having greater density than the usual non-volatile residue after ignition, or an unknown element. It is needless to say that the absence of such heavy substances as lead from the reagents was proved. From the variation in the values, assuming no error in manipulation, the oxide is not yet pure, butcareful fractionation, using much greater quantities of the material, gives good promise.

\section{EXPERIMENTS ON THE RADIO-ACTIVITY OF THE OXIDES.}

In writing of the now well recognized Becquerel rays, $M$. and Mme. Curie" say that "the property of emitting rays $* * *$ which act on photographic plates is a specific property of uranium and thorium." Sir William Crookes ${ }^{2}$ has practically proved that the radio-activity of uranium is due to a constant constituent, which can be partially fractioned out, $\operatorname{Ur}(\mathrm{X})$. In the same paper $\mathrm{Dr}$. Crookes presents the results obtained in a few preliminary experiments he made to separate thorium compounds into an active and inactive body. ${ }^{3}$ His experiments in fractioning thorium sulphate gave negative results. However when he obtained six fractions by crystallizing the nitrate, "the oxide from the first end crystals gave a feeble action, while the other end gave an impression about three times as intense. This points to the possibility of separating from thorium its radio-active substance" (p. 42I). My own experiments are in exact accord with the above. The oxide (sp. gr. 9.25) obtained from the insoluble citrate affects the sensitive plate in the dark after an exposure of seventy-two hours but slightly, while the oxides of higher specific gravity are quite active. A number of plates have been exposed, using oxides

1 Compt. rend., 127, I75; Chem. News, 78, 49 (1898).

2 Proc. Roy. Soc, 66, 409.

3 Loc. cit. 
obtained through the research, monazite sand from which the thorium salts were prepared, uranium nitrate, acetate, uraninite, and blanks for comparison. The radio-activity increased with the increase in specific gravity. For reasons given below I am of the opinion that the 9.25 thorium oxide is not quite pure, that is, free from traces of the higher oxide, hence its faint activity. (See above. Method of application is outlined below.)

I am not yet ready to assert that the new substance obtained is not the third radio-active body reported by Debierne in pitchblende, ${ }^{1}$ actinium, which, he states, belongs to the iron group. From Madame Curie's statement, Debierne supposes that the radio-active property observed in thorium compounds does not belong to this element, but is due to a foreign material, hence actinium (?). From Rutherford's experiments on induced radioactivity, one is loath to accept the radio-activity of unprotected bodies as sufficient evidence of their sameness. I have not so far had time to apply the radiant matter test, but amassing chemical evidence so far obtained points to the presence of a hitherto unrecognized body.

An account of the method used in these preliminary experiments on the radio-activity of thorium and its constituents may be of interest. The plan was essentially the same followed by Dr. Crookes, ${ }^{2}$ differing somewhat in details. Placing small circular pill boxes containing the materials directly on the same sensitive plates was not satisfactory on account of the excessive radiation from the concentrated active body in all directions. Black glazed paper, the size of the plate, was punctured with circular holes about I. 5 cmu. in diameter and placed dark side up on the plate. A sheet of silver-free lead, about $0.5 \mathrm{~mm}$. thick, was similarly cut and placed on the paper, which served to protect the plate. The material was placed in quantities varying from 0.25 to I gram in small exhibition glass tubes $1 \mathrm{~cm}$. in diameter and $5 \mathrm{~cm}$. tall. These cells were closed by sealing thin circular microscope slide covers to the flange with Canada balsam. After air-drying, the cells were inverted and the sealed end placed neatly over the circular openings in the lead and paper, thus exposing portions of the plate to the radiant action downward through a thin medium of glass and air, as the cells were not in contact

i Compt rend, October Io. I8go, and April 2, I000; Chem, heas, 8I, 169

2 Loc cit. 
with the sensitive surface nearest the tubes being held up by the flange, which projected beyond the circular opening. To eliminate lateral radiant action, each cell was then surrounded by a cylinder of lead, which was filed to fit snugly upon the sheet lead below. These cylinders were about $2.5 \mathrm{~cm}$. in diameter, inside, and $5.25 \mathrm{~cm}$. high. Such a battery, having from two to eight cells differently charged, was placed in a box, closed, covered with black glazed paper, several thicknesses of cloth and locked in a dark room for various lengths of time, 24 to 145 hours. The plates were afterwards developed.

\section{DETERMINATION OF THE ATOMIC WEIGHT OF THORIUM.}

As this is a preliminary paper, a detailed discussion of the various atomic weights accorded thorium by the several workers is beyond its scope and will be reserved for a subsequent communication. Suffice it to say the compounds made use of, as reported by Clarke, ${ }^{1}$ viz., the sulphate, oxalate, acetate, and formate, offer little promise of either concordant or satisfactory results. Brauner and Povlicek ${ }^{2}$ have recently called attention to a serious source of error in using the anhydrous sulphate. The careful work of Brauner on the heptahydrated thorium tetrammonium oxalate $^{3}$ gives good results for that substance, but in atomic weight work it is desirable to have as few factors as possible for consideration. It is a matter for surprise that none of the halogen compounds have ever been used. The tetrachloride was selected for this preliminary work. It may be that the bromide will yield even better results.

Preparation of Thorium. Tetrachloride.-Thorium dioxide was prepared from the purest insoluble citrate by intense ignition, ground to an impalpable powder in an agate mortar and an intimate mixture made with a thick paste composed of corn starch and pure sucrose sirup. Balls, $5^{-8} \mathrm{~mm}$. in diameter, were made from this, dried and baked at $140^{\circ}-150^{\circ} \mathrm{C}$. in a platinum milk pan until thoroughly browned. They were then heated in a closed platinum crucible with a Bunsen burner until thoroughly carbonized. About a dozen of these black pellets were placed into a perfectly clean dry combustion tube. Freshly prepared, pure dry chlorine was passed through the tube, that portion immediately

\footnotetext{
1 Smithsonian Institution, "Constants of Nature," v, rerised, 1897, p. 204.

2 Proc. Chem. Soc. (Lond.), 17, 63 (1901).

3 Chem. Soc. Trans. (Lond.), 75, 95 I (1898).
} 
surrounding the balls being heated to dull redness. At first a white vapor formed; some settled on the tube quite a distance from the heat and some was swept into the lime absorption tower by the chlorine. In Chydenius' paper ${ }^{1}$ it appears that Berzelius observed this "weisser dampf" and he states that it is not finely divided thorium chloride. This is the impurity which was noted above. Then beautiful fern-like crystals, only slightly volatile, began to form immediately over and on the balls. These crystals are the purest compound of thorium ever prepared in this laboratory." After two hours the heat was removed and the tube allowed to cool in a current of chlorine, which was subsequently removed by pure dry air free from carbon dioxide.

These crystals absorbed water and were quite soluble. The white volatile vapor mentioned was even more deliquescent. The fernoid crystals were dissolved in water, the solution made up to roo cc. in a standard flask, and aliquot portions measured out by means of a calibrated standard burette, whose outlet was so constricted as to deliver $0.0 \mathrm{I} \mathrm{cc}$. by drops.

Those portions taken for the determination of thorium were measured directly into weighed platinum crucibles, which were placed into perforations of a porcelain plate over a water-bath, and evaporated to dryness. The gelatinous oxychloride was gently heated first over a Bunsen burner and then ignited to a constant weight over the blast-lamp. A beautiful white glistening residue of thorium dioxide was obtained.

For the determination of chlorine, measured quantities were taken, diluted to $75 \mathrm{cc}$, and acidified with I to 2 drops pure nitric acid. Just below the boiling-point the chlorine was precipitated with a weighed quantity of silver nitrate prepared according to Stas. The precipitate was caught in a weighed Gooch crucible, the suction flask being placed in an asphalted box. The crucible and silver chloride were then dried in a dark air-bath at $140^{\circ}-150^{\circ}$ C. to a constant weight. The acid-washed asbestos from which the felt was made was previously digested in boiling hydrochloric acid, then water, then hot nitric acid, and finally washed with boiling water until not the faintest evidence of the presence of halogens was obtained.

1 Loc. cit.

$\because$ I was assisted in the preparation of the tetrachloride and dry ether by Dr. A. S. Wheeler, associate professor, to whom I wish to express thanks. 
The following are the results obtained :
Taken.
Thorium dioxide found.
A. $\left\{\begin{array}{l}25 \mathrm{cc} . \\ \text { Io } \mathrm{cc} .\end{array}\right.$
0.0903
Silver chloride found.
0,0812
Thorium dioxide found.
B. $\left\{\begin{array}{l}\text { I } 5 \mathrm{cc} . \\ \text { I } 5 \mathrm{cc} .\end{array}\right.$
$0,054^{2}$
Silver chloride found.
0.1220
Per $100 \mathrm{cc}$.
0.3612
Cl per $100 \mathrm{cc}$
0.2007
Per $100 \mathrm{cc}$.
0.36133
Cl per $100 \mathrm{cc}$.
0.20105

Calculations :

$\left.\begin{array}{l}\text { A. } \frac{\mathrm{XO}_{2}}{\mathrm{Cl}_{4}}=\frac{0.3612}{0.2007} . \quad \therefore \mathrm{X}=223.2 \\ \text { B. } \frac{\mathrm{XO}_{2}}{\mathrm{Cl}_{4}}=\frac{0.36133}{0.201056} . \quad \therefore \mathrm{X}=223.3\end{array}\right\}$ Atomic weight of thorium.

It is very interesting here to note that both Hermann's ${ }^{1}$ and Delafontaine' $s^{2}$ results obtained from $2 \mathrm{ThSO}_{4} \cdot 9 \mathrm{H}_{2} \mathrm{O}$ and corrected by the observations of Hillebrand ${ }^{3}$ to $\mathrm{ThSO}_{4} \cdot 4 \mathrm{H}_{2} \mathrm{O}$ give $223.06 \pm$ 3426 . On account of the doubt as to the composition of the sulphate and the wide divergence in the value obtained (223.23) from the accepted atomic weight of thorium, Clarke correctly threw it out of consideration. From the preliminary values obtained above, which were not reduced to a vacuum, the results assume importance.

As the tetrachloride is so readily decomposed by water and a direct comparison between a known amount of the tetrachloride and the oxide obtained therefrom is desirable, a complete analysis of the body was made.

Preparation of Pure Anhydrous Ether.-Ether, which had stood over calcium chloride for a year, was decanted over fresh fused calcium chloride and allowed to remain a week. It was then distilled and placed over freshly cut sodium and allowed to stand four days. It was again distilled and placed over fresh sodium and left three days until no more bubbles of hydrogen escaped. This process was repeated until fresh sheets of sodium showed no tarnishing and no hydrogen bubbles were observable. It was finally distilled. In all these operations special precautions were taken to prevent the absorption of a trace of moisture.

More tetrachloride was prepared and that part of the tube on each side and just above the pellets was placed in a perfectly dry Soxhlet apparatus. At the upper end of the reflux condenser

1 "Constants of Nature," Clarke, Part 5, revised, 1897, p. 204.

2 Axch. sci. phys, et nat., (2), 18, 343.

3 Bulletin 90, U. S. Geological Survey, p. 29. 
was attached a calcium chloride tube. After the apparatus was in place it was learned that the ground-glass connection of the condenser was not air-tight. A selected velvet cork was substituted. When the extraction had continned about six hours, it was discovered that an overlooked small defect of the cork had permitted the gradual introduction of about a drop of water, which came from the sweating of the condenser overhead. As this ritiated the experiment, the ether was evaporated and the whole dissolved in water. During the evaporation a small amount of hydrochloric acid was detected in the vapor. For that reason the experiment must be discarded, but the results are given :

whence

C. Thorium dioxide found ............. o. y 020

C. $\{$ Chlorine found ........................ 05636

$$
\frac{\mathrm{XO}_{2}}{\mathrm{C}_{+}} \cdots \frac{0.102}{0.05^{636}} \cdot \therefore 234.65=\text { atomic weight. }
$$

The pellets, which were covered with excrescences of crystals of the tetrachloride, were repeatedly shaken in a small Erlenmeyer flask with about ro cc. of pure dry ether. The ether was filtered directly into a weighed platinum crucible, which was placed in a vacuum desiccator, in the bottom of which was pure concentrated sulphuric acid and abore chipped paraffin. The tetrachloride appears to be soluble in about 1000 parts of dry ether. Proper precautions were taken to dry the air used to relieve the vacuum of the desiccator and prevent back rush of moist air from the pump. The crucible was dried at $105^{\circ} \mathrm{C}$. for half an hour in an air-bath already heated and weighed. The finely crystallized tetrachloride was dissolved in $2 \mathrm{cc}$. of pure distilled water to decompose the chloride and form the oxychloride, evaporated to dryness, ignited, and weighed. The following results were obtained:

Tetrachloride used.......... 0.0822 gram.

Dioxide found ............ 0.0574 gran.

$$
\text { Hence } \frac{\mathrm{XO}_{2}}{\mathrm{XCl}_{4}}=\frac{0.0574}{0.0822} \quad \ldots 222.13=\text { atomic weight. }
$$

In all calculations the following values were used: $O \ldots I 6$, $\mathrm{Cl}=35.45$, and $\mathrm{Ag}=107.93$.

Another ether extract was made as above, weighed and dissolved in water and the chlorine determined by titration with a standard silver nitrate solution, using potassium chromate as indicator,-method of Pelouze. Tetrachloride used, o.or gram;

1 Higher chlorine value decreases the atomic weight of thoriun. 
cubic centimeters of silver nitrate required, 3.9, each cubic centimeter being equivalent to 0.001 gram chlorine; hence 0.0039 gram chlorine or 39 per cent. The percentage of the oxide obtained from the chloride, 69.83 .

\begin{tabular}{|c|c|c|c|}
\hline & Calcu & $\mathrm{rhCl}_{4}$ & \\
\hline & 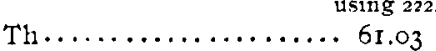 & $\begin{array}{l}\text { using } 223.3 . \\
61.18\end{array}$ & Found. \\
\hline & & & \\
\hline & $\mathrm{ThO}_{2} \ldots \ldots \ldots \ldots \ldots \ldots \ldots \ldots, 69.83$ & 70.17 & $69.8_{3}$ \\
\hline & $\mathrm{Cl}_{4} \ldots \ldots \ldots \ldots \ldots \ldots \ldots 3^{8.97}$ & 38.84 & 59.00 \\
\hline
\end{tabular}

These discrepancies do not deserve discussion as the data are far too few for ascribing the proper atomic weight to thorium. The last analysis is important, however, as we have secured a substance of known composition, which may be prepared pure and which lends itself for atomic weight determinations, as the dual constituents, thorium and chlorine, can be determined with accuracy. The figures hold interest however, as it may be asserted that the real mass equivalent of thorium is much below that hitherto ascribed to it. It is of greater interest to attribute the old values to a constant unknown impurity in practically all the materials used. This constituent must be an element of much higher atomic weight.

With this evidence of the complexity of thorium the problem now engrossing my personal attention is the separation of the compounds of this element, the proof of their purity and determination of the physical constants and chemical properties. From insufficient data already obtained, in case the element be tetravalent, it appears that the atomic weight lies between 260 and 280. On account of the extensive occurrence, in this state (North Carolina), of the monazite sands from which the original material was obtained, if the investigation give a successful issue, I should like to have the element known as Carolinium, with the symbol $\mathrm{Cn}$.

As this is a preliminary paper only, it may not be out of place to state the lines of research bearing immediately upon the subject that are already under way in this laboratory.

I. The preparation of an adequate quantity of perfectly pure thorium compounds with which to continue the study of the radio-activity, the spectrum, and to obtain sufficient tetrahalides 
for the determination of the true atomic weight of that element, which is assuredly different from the number usually accorded it and dependent at present upon evidence not wholly satisfactory.

2. An investigation of several of the old thorium compounds, like the hydrated sulphates, citrates, etc, and determination of their composition.

3. An investigation of the volatile chloride obtained in the preparation of the thotium tetrachloride.

ENIVERSTY of North čarolina, June $\mathrm{r}$, Igor.

\section{BOOKS RECEIVED.}

Commercial Fertilizers. By H. A. Huston, State Chemist, Purdue University. Published by the author. Lafayette, Ind. $32 \mathrm{pp}$.

Subject List of Works on Chemistry and Chemical Technology in the Library of the Patent Office. London. Io5 pp. Price, $6 \mathrm{~d}$.

Industrial Progress-Mills, Factories, Cattle, etc. The Bulletin of the North Carolina State Board of Agriculture, Raleigh, N. C. August, Igor. $32 \mathrm{pp}$.

Exhibit of the Bureau of Chemistry at the Pan-American Exposition, Buffalo, N. Y., Igor. Prepared under the direction of H. W. Wiiey, chief of bureau, by E. E. Ewell, W. D. Bigelow, and L. W. Page. Bulletin No. 63; U. S. Department of Agriculture, Washington, D. C. 29 pp. and IV plates.

Report of the Connecticut Agricultural Experiment Station for the Year Ending October 3I, I900. Part IV. Conclusion of the Report. Studies on the Vegetable Proteids. I 2 pp.

Connecticut Agricultural Experiment Station, New Haven, Conn. Bulletin 134, August, I90I. Entomological Series, No. 4, The New Law Concerning Insect Pests. 6 pp.

Leitfaden für den Unterricht in der anorganischen Chemie, didaktisch bearbeitet von Dr. Joachim Sperber. Zweiter Teil. Zürich : Verlag von E. Speidel. Igor. I63 pp. Price, M 2.40.

Influence of Wheat Farming upon Soil Fertility. Bulletin No. 70, Agricultural Experiment Station of the University of Minnesota. May, Igor. 20 pp.

Annual Report of the Commissioner of Patents for the Year rgoo. Washington: Government Printing Office. Igor. $394 \mathrm{pp}$.

The Chemistry of the Bark of Robinia Pseud-Acacia. By Frederick B. Power. No. 20. 23 pp. The Anatomy of the Bark of Robinia PseudAcacia. By Pierre Elie Felix Perrédès. No. 21. I5 pp. A Soluble Manganese Citrate and Some Compounds of Manganese with Iron. By Frederick B. Power. No. 22. Io pp. The Chemical Character of So-called Iodo-Tannin Compounds. By Frederick B. Power and Frank Shedden. No. 23. II pp. The Wellcome Chemical Research Laboratories, 6 King Street, Snow Hill, London, E. C. 